\title{
PENGARUH VARIASI SUHU DEMINERALISASI TERHADAP NILAI RENDEMEN DAN MOROFOLOGI PERMUKAAN PADA HASIL SINTESIS KITOSAN DARI LIMBAH TULANG CUMI
}

\author{
Iin Lidia Putama Mursal \\ Prodi Farmasi Fakultas Teknologi dan Ilmu Komputer Universitas Buana Perjuangan \\ Karawang (iin.lidia@ubpkarawang.ac.id)
}

\begin{abstract}
Abstrak
Penelitian ini dilakukan untuk mengetahui pengaruh suhu demineralisasi terhadap hasil sintesis kitosan dari tulang cumi. Variasi suhu demineralisasi yang digunakan pada penelitian ini adalah pada suhu $\pm 27^{\circ} \mathrm{C}$ dan $60^{\circ} \mathrm{C}$. hasil penelitian menunjukkan bahwa variasi suhu tersebut mempengaruhi nilai rendemen dan morfologi permukaan dari sampel kitosan yang dihasilkan. Nilai rendemen kitin dan kitosan yang dihasilkan berturut-turut adalah 29,75\% dan 22, $25 \%$ untuk suhu demineralisasi $= \pm 27^{\circ} \mathrm{C}$, kemudian 42,73 \% dan 29,58 \% untuk suhu demineralisasi $=60^{\circ} \mathrm{C}$. hasil SEM menunjukkan bahwa untuk suhu demineralisasi $\pm 27^{\circ} \mathrm{C}$ didapat ukuran partikel berkisar $22,78 \mu \mathrm{m}$ sedangkan untuk suhu demineralisasi $60^{\circ} \mathrm{C}$ ukuran partikelnya berkisar antara 10,44 sampai $22,42 \mu \mathrm{m}$

Kata kunci: Kitosan, tulang Cumi, SEM
\end{abstract}

\begin{abstract}
This research was conducted to determine the effect of demineralization temperature of chitosan from squids bone. This research using variation temperature $\pm 27^{\circ} \mathrm{C}$ and $60^{\circ} \mathrm{C}$. The result showed that variation give different effect on the yield and surface morphology of chitosan. The yields of chitin and chitosan which were produced successively were $29,75 \%$ and $22,25 \%$ for demineralization temperature $= \pm 27^{\circ} \mathrm{C} .42,73 \%$ and 29,58 $\%$ for demineralization temperature $=60^{\circ} \mathrm{C}$. SEM photograph show 22,78 $\mu$ m, and 10,44 - 24,22 $\mu \mathrm{m}$ average particle sizes for chitosan with variation of demineralization temperature $\pm 27^{\circ} \mathrm{C}$ and $60^{\circ} \mathrm{C}$.
\end{abstract}

Keywords : chitosan, squids bone, SEM

\section{PENDAHULUAN}

Indonesia merupakan negara kedua terbesar di dunia sebagai penghasil seafood (makanan laut). Tingkat konsumsi seafood di Indonesia juga semakin meningkat dari 
tahun ke tahun. Hal ini bisa terlihat dengan banyak restoran-restoran seafood yang tersebar di berbagai wilayah Indonesia. Salah satu jenis makanan laut yang banyak dikonsumsi adalah cumi.

Dalam pengolahan cumi, tulang cumi merupakan bagian yang dibuang dan menjadi limbah. Semakin banyaknya pengolahan cumi mengindikasikan semakin banyak pula limbah tulang cumi yang terbuang percuma tanpa adanya pemanfaatan lebih lanjutKitosan adalah jenis polimer alami yang dihasilkan dari proses deasetilasi kitin (Dounighi dkk, 2012). Contoh bahan alam yang dapat menghasilkan kitosan adalah cangkang udang, kepiting dan tulang cumi.

Material kitosan merupakan jenis material yang sedang banyak dikembangkan beberapa waktu belakangan ini. Hal ini disebabkan karena sifat kitosan yang bioaktifis, biokompatibel, biodegradasi, tidak beracun dan antimikroba (Agnihotri dkk, 2014). Sifat kitosan tersebut dapat diterapkan pada berbagai bidang, terutama dalam bidang farmasi dan kesehatan.

Terdapat tiga tahapan dalam pemproseasan bahan baku menjadi kitosan yaitu demineralisasi, deproteinisasi dan deasetilisasi. Dilatarbelakangi oleh hal tersebut, maka peneliti tertarik untuk melakukan penelitian mengenai sintesis dan karakterisasi kitosan dari limbah tulang cumi dengan variasi suhu demineralisasi. Diharapkan dari hasil penelitian bisa menjadi tambahan informasi mengenai parameter optimal dalam pengolahan limbah tulang cumi menjadi kitosan.

\section{METODE PENELITIAN}

\section{Bahan dan alat}

Bahan dan alat yang digunakan dalam penelitian ini antara lain tulang rawan cumi, $\mathrm{HCl}, \mathrm{NaOH} . \mathrm{AgNO}_{3}$, aquades, alcohol, magnetic stirer, neraca analitik, ayakan mesh 80, oven, dan untuk karakterisasi digunakan Scanning Electron Microscopy (SEM)

\section{Prosedur Penelitian}

Tulang rawan cumi yang telah kering yang dihaluskn kemuadian diayak dengan menggunakan ayakan 80 Mesh. Bahan berupa serbuk yang telah lolos ayakan siap untuk disintesis lebih lanjut menjadi kitosan. Proses sintesis bahan menjadi kitosan dilakukan melalui tiga tahap yaitu tahap penghilangan mineral (demineralisasi), tahap penghilangan protein (deproteinisasi) dan tahap produksi kitosan (deasetilasi). Bahan didirendam 
dengan $\mathrm{HCl} 1 \mathrm{M}$ dengan perbandingan antara tulang rawan cumi dan $\mathrm{HCl}$ 1:10 (b/v) selama 72 Jam. Kemudian dilakukan proses deminaralisasi dengan cara mengaduk campuran menggunakan magnetik stirer selama 3 jam dengan variasi suhu (suhu kamar dan suhu $60{ }^{\circ} \mathrm{C}$ ). setelah proses pengadukan selesai campuran disaring. Residu hasil penyaringan dicuci dengan menggunakan aquades dan disaring kembali. Bahan selanjutnya dikeringkan di dalam oven dengan suhu $70{ }^{\circ} \mathrm{C}$ hingga kering.

Tahapan selanjutnya adalah tahap penghilangan protein (deproteinisasi) bahan yang telah kering dicampur dengan $\mathrm{NaOH} 1 \mathrm{M}$ dengan perbandingan $1: 10(\mathrm{~b} / \mathrm{v})$ antara bahan dengan $\mathrm{NaOH}$. Campuran di stirrer dengan menggunakan magnetik stirrer selama 1 jam dengan suhu $60^{\circ} \mathrm{C}$. selanjutnya campuran disaring. Residu hasil penyaringan dicuci dengan aquades hingga $\mathrm{pH}$ bahan netral. Bahan yang sudah netral dikeringkan di dalam oven pada suhu $70{ }^{\circ} \mathrm{C}$. Tahap akhir sintesis kitosan dari tulang rawan cumi adalah deasetilisasi. Bahan yang telah kering dicampur dengan $\mathrm{NaOH} 50 \%$ dengan perbandingan bahan dengan $\mathrm{NaOH}$ 1:10 (b/v). campuran distirer dengan menggunakan magnetik stirer selama 2 jam pada suhu $90{ }^{\circ} \mathrm{C}$. kemudian disaring dengan menggunakan kertas saring lalu dinetralisasi dengan mencuci residu dengan aquades hingga $\mathrm{pH}$ netral. Bahan selanjutnya dikeringkan pada suhu $70{ }^{\circ} \mathrm{C}$. Kitosan yang sudah terbentuk selanjutnya dikarakterisasi dengan menggunakan SEM.

\section{PEMBAHASAN}

Hasil pengayakan dari serbuk tulang cumi kering dibagi menjadi 2 sampel. Sampel pertama di sintesis dengan suhu demineralisasi pada suhu ruang yaitu $\pm 27{ }^{\circ} \mathrm{C}$ dan sampel kedua pada suhu demineralisasi $60^{\circ} \mathrm{C}$. Pada tahap demineralisasi ini terjadi proses penghilangan kadar mineral dari bahan baku tulang rawan cumi.

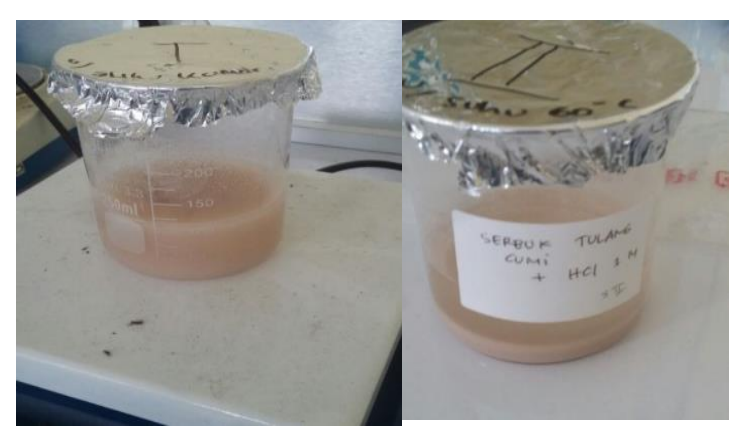

Gambar 1. Sampel 1 dan Sampel 2 
Setelah distirer dengan variasi suhu demineralisasi selama 3 jam, dilakukan proses pencucian dengan mennggunakan aquades hingga ion klorida yang terkandung hilang. Sisa penyaringan ditetesi dengan $\mathrm{AgNO}_{3}$ untuk menguji apakah pada bahan masih terdapat sisa ion klorida. Ketika sisa penyaringan pada proses penyaringan yang pertama ditetesi larutan $\mathrm{AgNO}_{3}$ cairan sisa penyaringan yang pada awalnya berwarna bening berubah warna menjadi putih susu. Perubahan warna ini dikarenakan ion $\mathrm{Ag}^{+}$dari laruan $\mathrm{AgNO}_{3}$ bereaksi dengan $\mathrm{Cl}^{-}$dari $\mathrm{HCl}$.

$\mathrm{Hal}$ ini mengindikasikan bahwa masih terdapat kandungan $\mathrm{HCl}$ didalam sampel. Oleh sebab itu dilakukan kembali pencucian dengan menggunakan aquades bebrapa kali. Hingga pada pencucian kelima sudah tidak mengalami perubahan warna. Tidak adanya perubahan warna pada cairan sisa penyaringan mengindikasin bahwa bahan hasil penyaringan sudah tidak mengandung ion klorida.

Tahap berikutnya adalah deproteinisasi dengan menggunakan $\mathrm{NaOH} 1 \mathrm{M}$. Sampel distirer selama $1 \mathrm{Jam}$ dengan suhu $60^{\circ} \mathrm{C}$ Pada tahap deproteinisasi ini terjadi proses pelepasan ikatan antara protein dan kitin yang terkandung di dalam tulang rawan cumi.

Proses ini akan melepaskan protein dengan membentuk Na-proteinat yang dapat larut. Setelah proses deproteinisasi selesai selanjutnya sampel dinetralkan dari kandungan $\mathrm{NaOH}$ dengan mencuci sampel menggunakan aquades. Sisa penyaringan diuji dengan $\mathrm{pH}$ Universal. Pada hasil pencucian pertama kali terlihat bahwa kadar $\mathrm{pH}=14$ (basa), kadar tersebut berarti bahwa sampel masih mengandung $\mathrm{NaOH}$ yang merupakan basa kuat. Dilakukan pencucian berulang hingga pada pencucian ke-6 hasil pada $\mathrm{pH}$ universal menunjukkan kadar $\mathrm{pH}=7$. Hal ini mengindikasikan bahwa sampel telah netral dan bebas dari kandungan $\mathrm{NaOH}$.

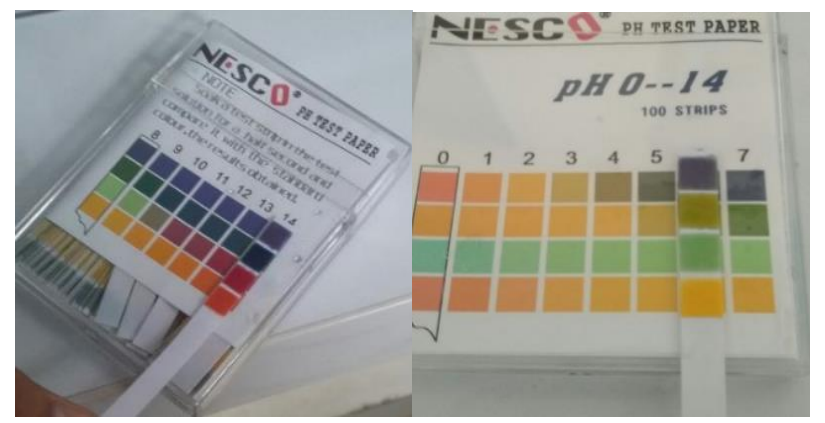

(a)

(b)

Gambar 2. (a) Hasil pengujian pH pada pencucian pertama (b) hasil pengujian pada pencucian ke-6 
Tahap terakhir dari sintesis kitosan adalah deasetilisasi menggunakan $\mathrm{NaOH} 50$ $\%$ pada suhu $90{ }^{\circ} \mathrm{C}$. Deasetilasi adalah proses penghilangan asetil yang terdapat dalam kitin limbah tulang rawan cumi. Proses deasetilasi dipengaruhi oleh tiga faktor antara lain konsentrasi $\mathrm{NaOH}$, temperatur reaksi dan waktu reaksi (Tolaimatea dkk,2003).

Nilai rendemen yang dihitung pada penelitian ini adalah adalah nilai rendemen kitin yang dihasilkan dari tulang rawan cumi dan nilai rendemen kitosan yang dihasilkan dari kitin yang diperoleh. Data nilai rendemen dapat dilihat pada tabel 1 berikut :

Tabel 1. Persentase Rendemen Kitosan

\begin{tabular}{|c|c|c|l|}
\hline Sampel_ & $\begin{array}{c}\text { Suhu } \\
\text { demineralisasi }\end{array}$ & $\begin{array}{c}\text { Rendemen } \\
(\%)\end{array}$ & \multicolumn{1}{|c|}{ Keterangan } \\
\hline 1 & $\mathrm{~T}= \pm 27^{\circ} \mathrm{C}$ & 29,75 & Rendemen Kitin \\
\hline 2 & $\mathrm{~T}=60^{\circ} \mathrm{C}$ & 42,73 & Rendemen Kitin \\
\hline 1 & $\mathrm{~T}= \pm 27^{\circ} \mathrm{C}$ & 22,25 & Rendemen Kitosan \\
\hline 2 & $\mathrm{~T}=60^{\circ} \mathrm{C}$ & 29,58 & Rendemen Kitosan \\
\hline
\end{tabular}

Dari data pada tabel 1 dapat dilihat bahwa \% hasil rendemen kitosan berbeda pada kedua sampel. Sampel 2 yang dimeneralisasi dengan $\mathrm{HCl}$ pada suhu $60{ }^{\circ} \mathrm{C}$ menghasilkan rendemen kitosan yang lebih tinggi dibandingkan dengan sampel 1 yang dimeneralisasi pada suhu ruang $\left( \pm 27^{\circ} \mathrm{C}\right)$.

Perbedaan hasil rendemen memperlihatkan bahwa variasi suhu demineralisasi dengan $\mathrm{HCl}$ mempengaruhui nilai rendemen dari kitosan. Menurut Rachmania (2011) Mineral memiliki sifat larut asam. Perendaman tulang rawan cumi di dalam $\mathrm{HCl} 1 \mathrm{M}$ menyebabkan matrik cangkang udang mengembang. Pengembangan ini menyebabkan pelarut mudah masuk ke dalam matrik. Suhu demineralisasi yang berbeda menyebabkan reaksi yang berbeda pada $\mathrm{HCl}$ dan bahan baku. Semakin tinggi suhu maka laju reaksi akan semakin meningkat. Peningkatan reaksi $\mathrm{HCl}$ akan mempengaruhi penurunan kadar mineral pada proses pembuatan kitin. Selain itu suhu yang leih tinggi akan membuat poripori serbuk tulang rawan cumi terbuka lebih maksimal sehingga ruang-ruang yang terbentuk memudahkan untuk dicapai oleh pengekstrak (HCL). Oleh sebab itu Semakin tinggi suhu maka semakin banyak rendemen kitin yang terbentuk sehingga kitosan yang terbentuk pun akan lebih banyak. 


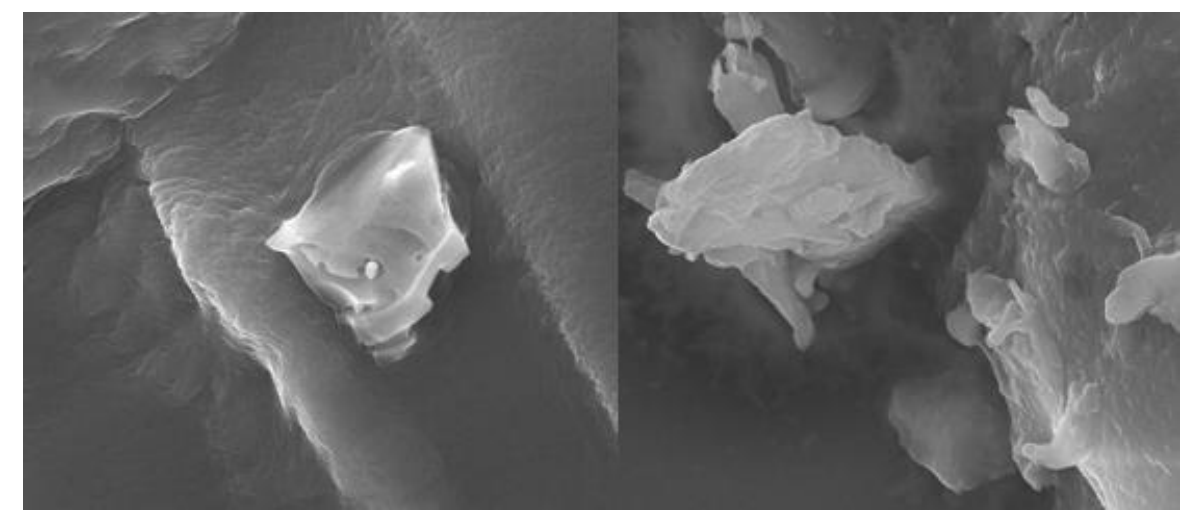

(a)

(b)

Gambar 3. Hasil SEM perbesaran 5000 kali dari kitosan dengan variasi suhu deminaralisasi (a) suhu ruang (b) suhu $60{ }^{\circ} \mathrm{C}$

Gambar 3 merupakan hasil karakterisasi SEM dari kitosan dengan variasi suhu demineralisasi untuk pembesaran 5000 kali. SEM digunakan untuk mengetahui struktur morfologi permukaan sampel kitosan. Prinsip kerja alat SEM ini adalah interaksi antara berkas elektron yang dikenakan pada sampel atau atom-atom sampel. Hasil SEM pada gambar 3.a merupakan morfologi permukaan dari sampel kitosan dengan suhu demineralisasi pada suhu ruang $\left( \pm 27^{\circ} \mathrm{C}\right)$ dengan ukuran grain $\pm 22,78 \mu \mathrm{m}$. Kemudian untuk suhu demineralisasi $60^{\circ} \mathrm{C}$ ukuran grain sampel kitosan berkisar 10,44 sampai $24,22 \mu \mathrm{m}$. Dari data tersebut dapat diketahui sampel kitosan dengan suhu demineralisasi yang lebih tinggi menghasilkan ukuran partikel yang secara rata-rata lebih kecil. Semakin kecil ukuran partikel tersebut maka luas permukaan partikel semakin besar. Semakin luas permukaan partikel maka atom-atomnya akan semakin reaktif dan hal akan mengoptimalisasi penggunaan sampel tersebut.

\section{PENUTUP}

Berdasarkan penelitian yang telah dilakukan dan hasil yang telah diolah dapat disimpulkan bahwa nilai persentase rendemen kitosan optimal didapat pada sampel dengan variasi suhu demineralisasi $60{ }^{\circ} \mathrm{C}$. Semakin tinggi suhu semakin banyak rendemen kitosan yang dihasilkan karena suhu meningkatkan laju reaksi dari pengekstrak $\mathrm{HCl}$ dan membantu terbukanya pori-pori serbuk tulang rawan cumi sehingga mudah dicapai oleh $\mathrm{HCl}$ dan mineral mudah terekstrak. Selain itu suhu yang lebih tinggi juga menghasilkan ukuran partikel sampel kitosan dengan rata-rata luas permukaan yang lebih luas. 


\section{DAFTAR PUSTAKA}

Agnihotri SA, Mallikarjuna NN, Aminabhavi TM. 2014. Recent advances on chitosan based micro- and nanoparticles in drug delivery. J Control Release. 2004;100(1):528.

Dounighi ,Eskandari R, Avadi MR, Zolfagharian H. 2012. The Journal of Venomous Animals and Toxins including Tropical Diseases volume Preparation and in vitro characterization of chitosan nanoparticles containing Mesobuthus eupeus scorpion venom as an antigen delivery system. 18 issue 1 pages 44-52

KhanTA, Kok K, Hung S. 2002. Reporting degree of deacetylation values of chitosan: the influence of analytical methods. JPharm Pharmaceut Sci5:205-212

Bhumkar DR. dan Pokharkar VB. 2006. Studies on effect of pH on Cross-linking of Chitosan with Sodium Tripolyphosphate: A Technical Note. AAPS PharmSciTech, 7(2):E1-E6

Kafshgari MH, Khorram M, Khodadoost M, Khavari S, 2011. Reinforcement of Chitosan Nanoparticles Obtained by an Ionic Cross-linking Process. Iran. Polymer J., 20(5):445:456

López-León T., Carvalho ELS., Seijo B., Ortega-Vinuesa JL., Bastos-Gozáles D., 2005. Physicochemical characterization of chitosan nanoparticles: elestrokinetic and stability behavior, J. Colloid and Interface Sci., 283:344-35

Suwarda R, Maarif MS. 2012. Pengembangan inovasi teknologi nanopartikel berbasis pati untuk menciptakan produk yang berdaya saing. Jurnal Teknik Industri 13(2):105-122

Tolaimatea, A.; Desbrieresb, J.; Rhazia, M., dan Alaguic, A., 2003, Contribution to the preparation of chitins and chitosans with controlled physico-chemical properties, Polym. J., 44, 7939-7952 